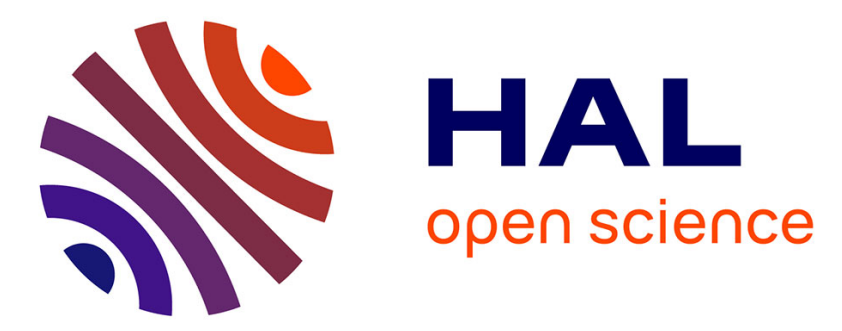

\title{
Synthesis, structural and Raman spectroscopic in organic-inorganic halide perovskites based on $\beta$-Alanine
} Abdellah Kaiba, Mohammed Geesi, Philippe Guionneau, Talal Aljohani, L. Bih, H. Bih, S. Kassou

\section{- To cite this version:}

Abdellah Kaiba, Mohammed Geesi, Philippe Guionneau, Talal Aljohani, L. Bih, et al.. Synthesis, structural and Raman spectroscopic in organic-inorganic halide perovskites based on $\beta$-Alanine. Journal of Molecular Structure, 2020, 1204, 127380 (7 p.). 10.1016/j.molstruc.2019.127380 . hal02572100

\section{HAL Id: hal-02572100 \\ https://hal.science/hal-02572100}

Submitted on 10 Sep 2020

HAL is a multi-disciplinary open access archive for the deposit and dissemination of scientific research documents, whether they are published or not. The documents may come from teaching and research institutions in France or abroad, or from public or private research centers.
L'archive ouverte pluridisciplinaire HAL, est destinée au dépôt et à la diffusion de documents scientifiques de niveau recherche, publiés ou non, émanant des établissements d'enseignement et de recherche français ou étrangers, des laboratoires publics ou privés. 


\title{
Synthesis, Structural and Raman Spectroscopic in Organic-Inorganic Halide Perovskites
}

\section{Based on $\beta$-Alanine}

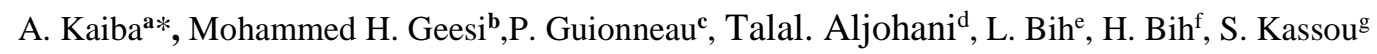

a Department of Physics, College of Science and Humanities in Al-Kharj, Prince Sattam bin Abdulaziz University, Al-

Kharj 11942, Saudi Arabia

${ }^{\mathbf{b}}$ Department of Chemistry, College of Science and Humanities in Al-Kharj, Prince Sattam bin Abdulaziz University, Al-

Kharj 11942, Saudi Arabia

c CNRS, Univ. Bordeaux, ICMCB, UPR 9048, 87, Avenue du Docteur Schweitzer, F-33600 Pessac, France

${ }^{\mathrm{d}}$ King Abdulaziz City for Science and Technology, Riyadh, Saudi Arabia.

e Département matériaux et procédés, ENSAM Meknes, Université Moulay Ismail, Meknes, Morocco

f laboratoire LMSNM, Faculté polydisciplinaire de Taza, université sidi Mohamed ben Abdellah, Fes, Morocco

g Département de physique, Faculté des science de Meknes, Université Moulay Ismail, Meknes, Morocco

\begin{abstract}
The amino acid copper chlorides $\left[\mathrm{NH}_{3} \mathrm{C}_{2} \mathrm{H}_{4} \mathrm{CO}_{2} \mathrm{H}\right]_{2} \mathrm{CuCl}_{4}$ is a new member of the family of organicinorganic hybrid like perovskite system. This compound crystallizes in the monoclinic space group $\mathrm{C} 2 / \mathrm{c}$ with unit cell parameters $\mathrm{a}=25.1209(3) \AA, \mathrm{b}=7.7432(2) \AA, \mathrm{c}=7.4130(2) \AA, \beta=105.293(2)^{\circ}$ and $\mathrm{Z}=4$. The molecule formula consists of a combination of $\left[\mathrm{CuCl}_{4}\right]^{2-}$ anions and two twisted organic $\left[\mathrm{NH}_{3}\left(\mathrm{CH}_{2}\right)_{2} \mathrm{CO}_{2} \mathrm{H}\right]^{+}$cations to form a two-dimensional perovskite system. Three dimensional hydrogen - bonding network is assuring the cohesion between these layers to stabilize the crystal. The micro-Raman spectroscopy measurement technique is used to probe organic-inorganic halide perovskite vibration modes and to study the effect of laser beam power on the intensity of Raman lines.
\end{abstract}

Keywords: Layered perovskite, organic-inorganic hybrid, single crystal structure, Micro-Raman spectroscopy

*Corresponding author:

E-mail address: a.kaiba@psau.edu.sa (A. Kaiba)

Address: Department of physics, College of Science and Humanities in Al-Kharj, Prince sattam bin Abdulaziz University, Al-Kharj 11942, Saudi Arabia 


\section{Introduction}

Layered organic-inorganic hybrids like perovskite system, with the general chemical formula $\mathrm{ABX}_{3}$ (A being the organic cation, B is Metal, and X the halide), have been widely studied [1]. Such molecules are considered as important materials because their combination of intrinsic organic (insulating) and inorganic (semiconducting) structures is similar to the natural quantum-well combination and compared to many other materials, their energy band gap can be easily adjusted by the modification of the halogen atom or by changing the alkyl substituent at the ammonium cation [2]. These materials exhibit a rich structural, optical, magnetic, electronic behavior and that remain the materials of choice for photovoltaic. Indeed, in 2012, new organic inorganic hybrids have made their official entry into the world of photovoltaics with the first approved cell with an efficiency of $12 \%$. The performance of solar cell based on these organic inorganic hybrids has increased rapidly to reach $20 \%$ in 2014 [3-5], approaching the performance of solar cells based on silicon and very efficient than solar cell based on organic molecules. The challenge now is to develop materials based on inexpensive materials, with high conversion efficiency and reduced manufacturing time to minimize the cost [6]. To study such chemical system in terms of the small number of variables could be useful [7-10]. Recently, new organic inorganics hybrids of collectors of solar energy based on lead, tin, palladium, halide and $\mathrm{R}-\mathrm{NH}_{2}$ has fascinated the scientific community. Their production process makes them very inexpensive because they are made from abundant elements and without loss of heat energy. The rapid rise in energy conversion efficiency is seen in photovoltaic devices $\left(\mathrm{PbI}_{3} \mathrm{CH}_{3} \mathrm{NH}_{3}\right)$ based on a short organic chain [11-17]. The monoamine chain can be replaced with an amino acid to add more hydrogen bonds between the carboxylic function group and from a 3Dimentional stable network not seen in other inorganic-organic hybrids like the perovskite system [18-20]. Here, the organic chain is 3-Aminopropionic acid ( $\beta$-Alanine), which has a carboxylic acid and amine function groups that are separated by two methylene groups and copper chloride. The Jahn-Teller effect produced by $\mathrm{Cu}^{2+}$ Metal cation introduces an additional flexibility into the inorganic framework, which also affects hydrogen bonding network. This causes distortion of the $\mathrm{CuCl}_{6}$ octahedron leading to an elongation of two equatorial $\mathrm{Cu}-\mathrm{Cl}$ bonds within the octahedral coordination $[\mathbf{2 1}, \mathbf{2 2}]$. The short bond length is relatively constant, whereas the semi-coordinate bond is significantly flexible, allowing to a more flexible inorganic layer structure, which facilitates the incorporation of the organic ammonium cations into the two-dimensional structure.

In this work, we present the crystal structure of $\left(\mathrm{NH}_{3}-\left(\mathrm{CH}_{2}\right)_{2}-\mathrm{COOH}\right)_{2} \mathrm{CuCl}_{4}$ and micro-Raman spectroscopy as a well-suited measurement technique to probe organic-inorganic halide perovskite layers locally on the micrometer scale by using different excitation laser intensities. According to the literature, most of the work that has been performed on organic-inorganic compounds uses a power 
laser: $\mathrm{p}=5 \mathrm{~mW}[\mathbf{2 3}, \mathbf{2 4}]$. Few scientists have studied the effect of laser beam power on the intensity of Raman lines. Generally, the interaction of the wave with the hybrid materials depends strongly on the nature of organic and/or inorganic compounds. It would be useful to study the effect of such power on the shape of the Raman spectra.

\section{Experimental Section}

The yellow single crystals of $\left[\mathrm{NH}_{3}-\left(\mathrm{CH}_{2}\right)_{2}-\mathrm{COOH}\right]_{2} \mathrm{CuCl}_{4}$ were obtained from a mixture between two solutions: the first solution obtained by the dissolution of amino-acid $\left(\mathrm{NH}_{2}-\left(\mathrm{CH}_{2}\right)_{2}-\mathrm{CO}_{2} \mathrm{H}\right)$ in distilled water and protonated by approximately 1 milliliter of hydrochloric acid $(\mathrm{HCl} \mathrm{37 \% )}$ and the second solution is obtained by the dissolution of copper chloride in distilled water. The resulting solution was left for two weeks at $25^{\circ} \mathrm{C}$. Structural properties of the synthesized compound was investigated by Raman spectroscopy using a SENTERRA II Compact Raman Microscope from Brucker with a wavelength of radiation $\lambda=532 \mathrm{~nm}$ and a different power on the sample in $50-4000 \mathrm{~cm}^{-1}$ range. A Nonius_Kappa_CCD diffractometer with a Molybdenum anticathode was used to collect the full data. The $\phi$ and $\omega$ scans mode was used and the distance crystal-detector was $35 \mathrm{~mm}$. Further details are shown in Table 1. The DENZO-SMN program was used to reduce the data. The SIR 97 program allowed us to have a structural hypothesis [25] and the SHELX 97 allowed us to refine all the atomic parameters using the full-matrix least squares technique on squared structure factor $\mathrm{F}^{2}$ [26]. Hydrogen atoms were located theoretically and refined anisotropically. All these programs were used within the WINGX package [27]. The DIAMOND [28] and MERCURY [29] programs were used for all the graphics. One can find the structure data in CCDC as supplementary publication. Deposition number 1956913. 
Table1: X-ray diffraction and crystal data of the organic-inorganic hybrid $\left[\mathrm{NH}_{3}\left(\mathrm{CH}_{2}\right) 2 \mathrm{COOH}\right]_{2}$ $\mathrm{CuCl}_{4}$

\begin{tabular}{|c|c|}
\hline Crystal data & CCOOHCuCl \\
\hline Identification code & Shelx \\
\hline Empirical formula & $\mathrm{C}_{6} \mathrm{H}_{16} \mathrm{Cl}_{4} \mathrm{Cu} \mathrm{N} \mathrm{N}_{2} \mathrm{O}_{4}$ \\
\hline Formula weight & 385.55 \\
\hline Temperature & 293(2) K \\
\hline Wavelength & $0.71073 \AA$ \\
\hline Crystal system & Monoclinic \\
\hline Space group & $\mathrm{C} 2 / \mathrm{c}$ \\
\hline Unit cell dimensions & $\mathrm{a}=25.1209(3) \AA$ \\
\hline & $\begin{array}{l}\mathrm{b}=7.7432(2) \AA, \beta=105.293(2) \\
\mathrm{c}=7.4130(2) \AA\end{array}$ \\
\hline Volume & $1390.89(4) \AA^{3}$ \\
\hline $\mathrm{Z}$ & 4 \\
\hline Density (calculated) & $1.841 \mathrm{Mg} / \mathrm{m}^{3}$ \\
\hline Absorption coefficient & $2.341 \mathrm{~mm}^{-1}$ \\
\hline $\mathrm{F}(000)$ & 780 \\
\hline Crystal size & $0.08 \times 0.05 \times 0.02 \mathrm{~mm}^{3}$ \\
\hline Theta range for data collection & 2.76 to $26.35^{\circ}$. \\
\hline Index ranges & $-29<=\mathrm{h}<=31,-9<=\mathrm{k}<=8,-9<=1<=7$ \\
\hline Reflections collected & 4264 \\
\hline Independent reflections & $1425[\mathrm{R}$ (int) $=0.0573]$ \\
\hline Completeness to theta $=26.35^{\circ}$ & $99.7 \%$ \\
\hline Absorption correction & Empirical \\
\hline Max. and min. transmission & 0.954 and 0.829 \\
\hline Refinement method & Full-matrix least-squares on $\mathrm{F}^{2}$ \\
\hline Data / restraints / parameters & $1425 / 0 / 79$ \\
\hline Goodness-of-fit on $\mathrm{F}^{2}$ & 1.139 \\
\hline Final $R$ indices $[I>2 \operatorname{sigma}(\mathrm{I})]$ & $\mathrm{R} 1=0.0372, \mathrm{wR} 2=0.1114$ \\
\hline $\mathrm{R}$ indices (all data) & $\mathrm{R} 1=0.0526, \mathrm{wR} 2=0.1178$ \\
\hline Largest diff. peak and hole & 0.537 and -0.603 e. $\AA^{-3}$ \\
\hline
\end{tabular}

\section{Results and Discussion}

\section{2-1 Structure description:}

The titled compound crystallizes in monoclinic system with $\mathrm{C} 2 / \mathrm{c}$ space group, $\mathrm{a}=25.1209(3) \AA$, $\mathrm{b}=$ 7.7432(2) $\AA, c=7.4130(2) \AA$ and $\mathrm{Z}=4$. The asymmetric unit cell consists of two entities $\left[\mathrm{CuCl}_{2}\right]^{-}$ (Site Occupation Factor of copper is 0.5 ) and protonated $\left[\mathrm{NH}_{3}(\mathrm{CH} 2)_{2} \mathrm{CO}_{2} \mathrm{H}\right]^{+}$cation (Fig.1). The formula unit of the compound $\left[\mathrm{NH}_{3}(\mathrm{CH} 2)_{2} \mathrm{CO}_{2} \mathrm{H}_{2} \mathrm{CuCl}_{4}\right.$ is composed by an anionic entity, constituted by the complex anion $\left[\mathrm{CuCl}_{4}\right]^{2-}$ that has a planar square structure typical for $\mathrm{Cu}(\mathrm{II})$, and two organic protonated cations $\left[\mathrm{NH}_{3}(\mathrm{CH} 2)_{2} \mathrm{CO}_{2} \mathrm{H}\right]^{+}$which form the cationic part.

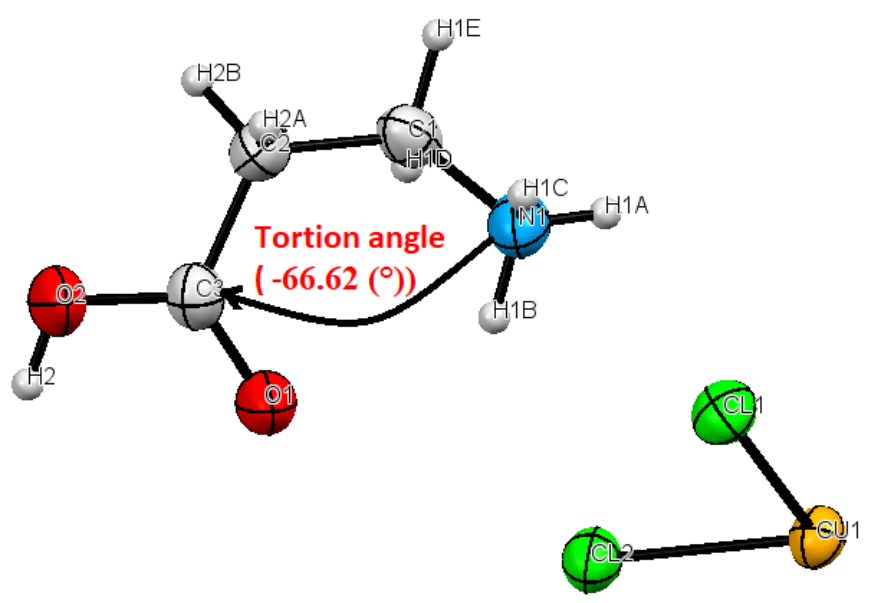

Figure 1: Molecular structure unit obtained at room temperature. 
The $\mathrm{Cu}$ atom, lying on an inversion center, is surrounded by four bridging and two terminal $\mathrm{Cl}$ atoms, forming a coordination geometry of octahedron sharing the corners with four adjacent octahedral through the bridging $\mathrm{Cl}$ atoms. The antiferrodistortive Jahn-Teller distortion effect produced by $\mathrm{Cu}^{2+}$ Metal cation introduces distortion of the $\mathrm{CuCl}_{6}$ octahedron leading to an elongation of two equatorial $\mathrm{Cu}-\mathrm{Cl}$ bonds within the octahedral coordination. Indeed, adjacent copper ions are thus linked by one normal and one semicoordinate bond to bridging halide ions in this antiferrodistortive arrangement. The two equatorials bonds (semicoordinate) $\mathrm{Cu}$---Cl lengthened distances are about $3.081 \AA$, the two other equatorials bonds (normal) $\mathrm{Cu}-\mathrm{Cl}$ are about $2.309 \AA$, the $\mathrm{Cu}-\mathrm{Cl}$ axial bonds (normal) close to $2.275 \AA$ and the bridging $\mathrm{Cu}-\mathrm{X} \cdots \mathrm{Cu}$ angle is $167.77\left(^{\circ}\right.$ ), indicative of the distortion between the adjacent octahedra (Fig.2). The bond angles around the $\mathrm{Cu}$ atoms vary from about $88.36\left(^{\circ}\right)$ to $91.55\left(^{\circ}\right)$.

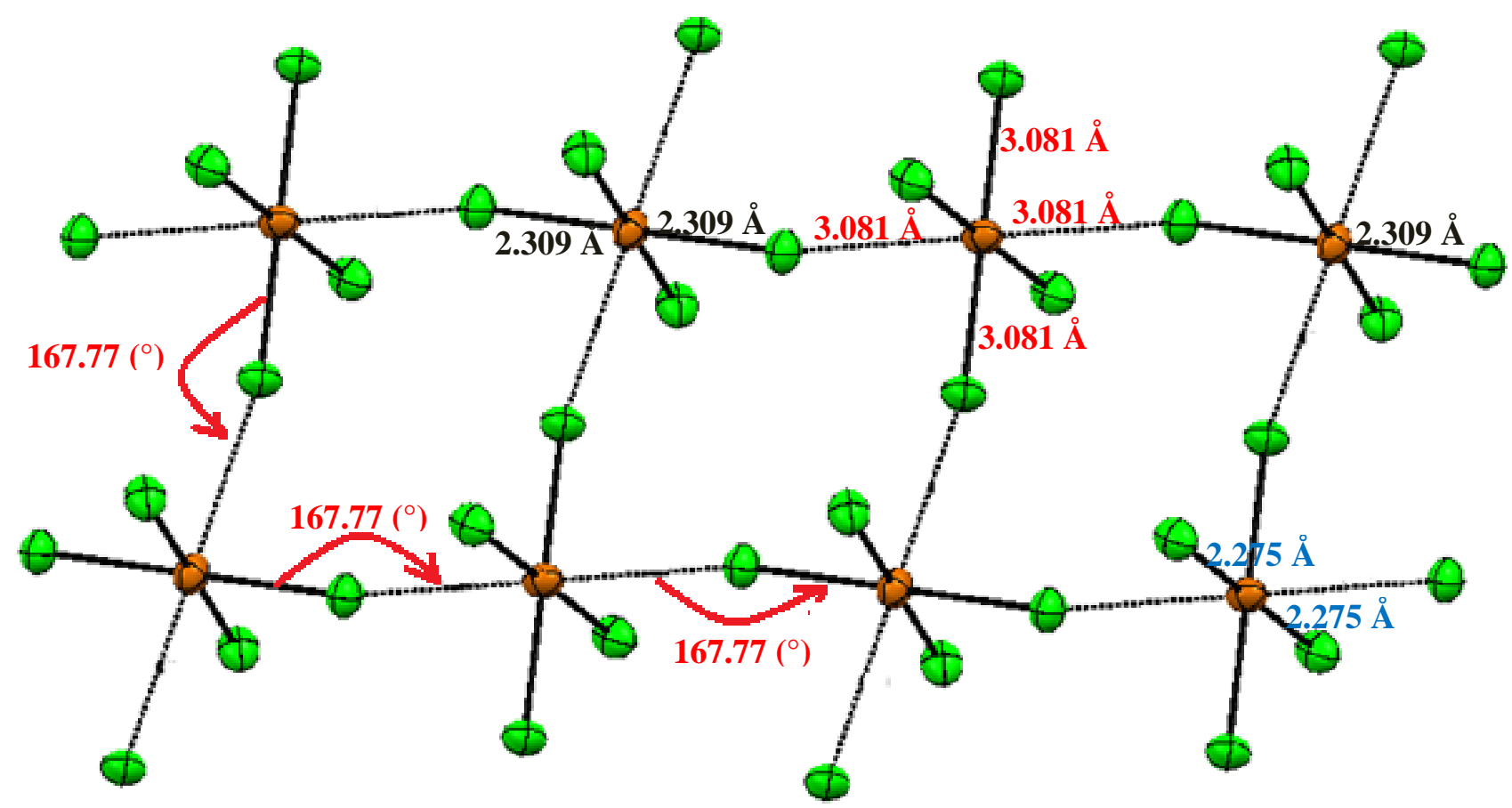

Figure 2: Schematic representation of the inorganic layers parallel to the $(b, c)$ plane

The anionic layers are separated by the $\beta$-Alanine cation bilayers, forming the inorganic-organic layered structure with the general formula $\mathrm{K}_{2} \mathrm{FX}_{4}(\mathrm{~K}=$ monovalent cation, $\mathrm{X}=$ halogen atom, $\mathrm{F}$ is a transition metal ion). The structure can be described by an alternation of organic and inorganic sheets stacked along a-axis. The distance between two adjacent inorganic layer is $d_{\text {inter }}=12.116 \AA$ (Fig.3.). Inside the inorganic sheet, the short distance between neighboring $\mathrm{Cu}$ metallic sites is $\mathrm{d}_{\text {intra }}=5.360 \AA$ in $\mathrm{c}$-axis direction and $\mathrm{d}_{\text {intra }}=7.743 \AA$ in $\mathrm{b}$-axis direction. 


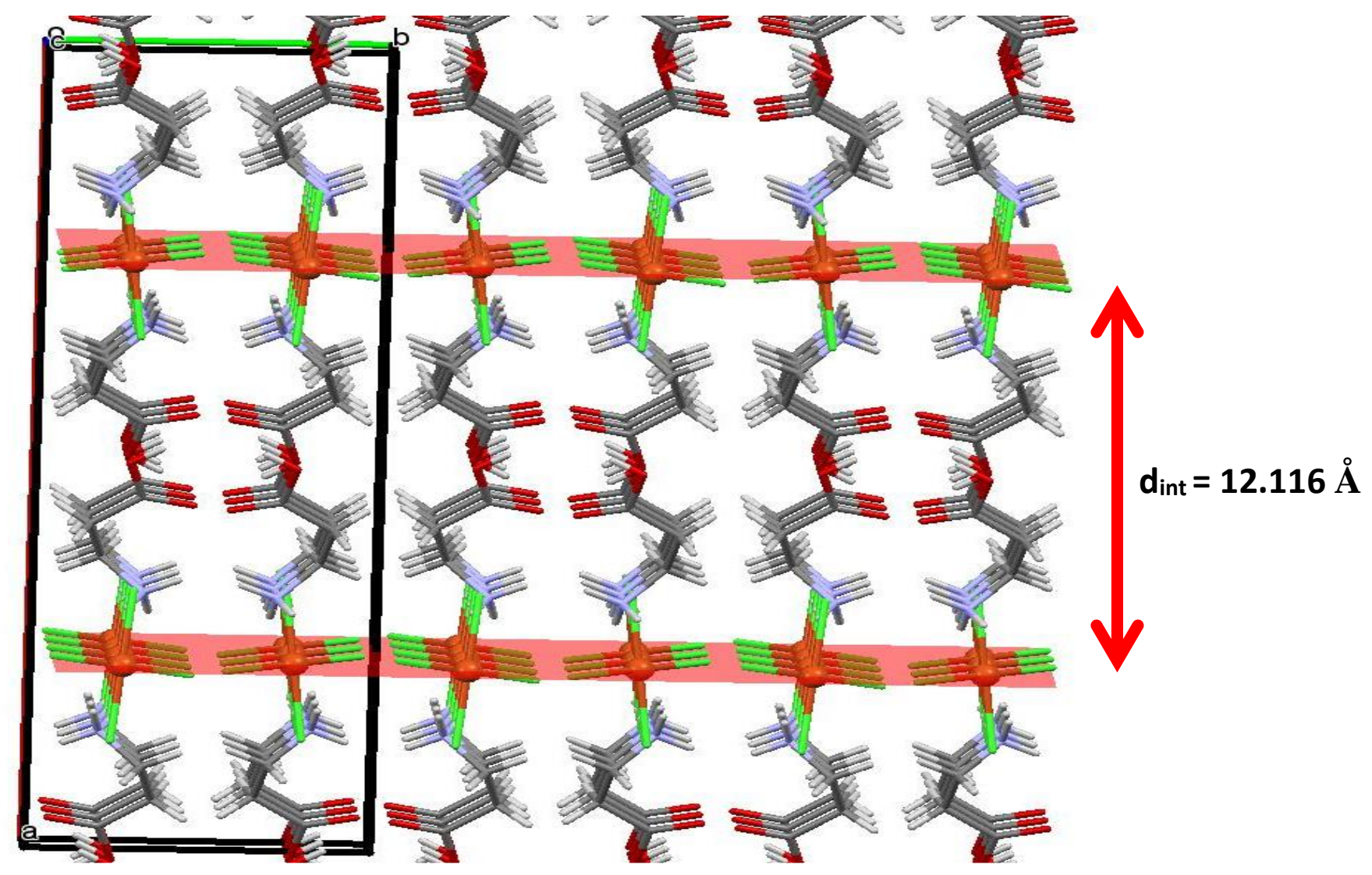

Figure 3: View according to c-axis showing the alternation between the organic and inorganic layers of $\left(\mathrm{NH}_{3} \mathrm{C}_{2} \mathrm{H}_{4} \mathrm{CO}_{2} \mathrm{H}\right)_{2}\left[\mathrm{CuCl}_{4}\right]$.

The $\beta$-Alanine ( $\left.{ }^{+} \mathrm{NH}_{3}(\mathrm{CH} 2)_{2} \mathrm{CO}_{2} \mathrm{H}\right)$ cation, locating in the cavities enclosed by the $\mathrm{CuCl}_{6}$ octahedra, are totally ordered and are linked to the $\left[\mathrm{CuCl}_{4}\right]^{2-}$ network through the hydrogen bonding interactions between their head $\mathrm{NH}_{3}$ groups and $\mathrm{Cl}$ atoms (Fig. 4). The interlayer cohesion is performed by tree hydrogen bonds type ( $\mathrm{NH} \ldots \mathrm{Cl}, \mathrm{CH} \ldots \mathrm{Cl}$ and $-\mathrm{COOH} \ldots . . \mathrm{O})$. The hydrogen bond geometries are in the normal norm ( NH....Cl distances: $2.432 \AA, 2.464 \AA$ and $2.460 \AA$ ) and (CH....Cl distances: 2.848 $\AA$; $2.900 \AA$ ). Also, acid function (-COOH) of neighboring chains form hydrogen bond interaction (COO-H...O) (OH....O distance: $1.888 \AA$ ) and allows dimer formation (Fig. 5 ). The hydrogen bond network caused the twist of the organic chain, the torsion angle NCCC is about $-66.62\left(^{\circ}\right)$. 


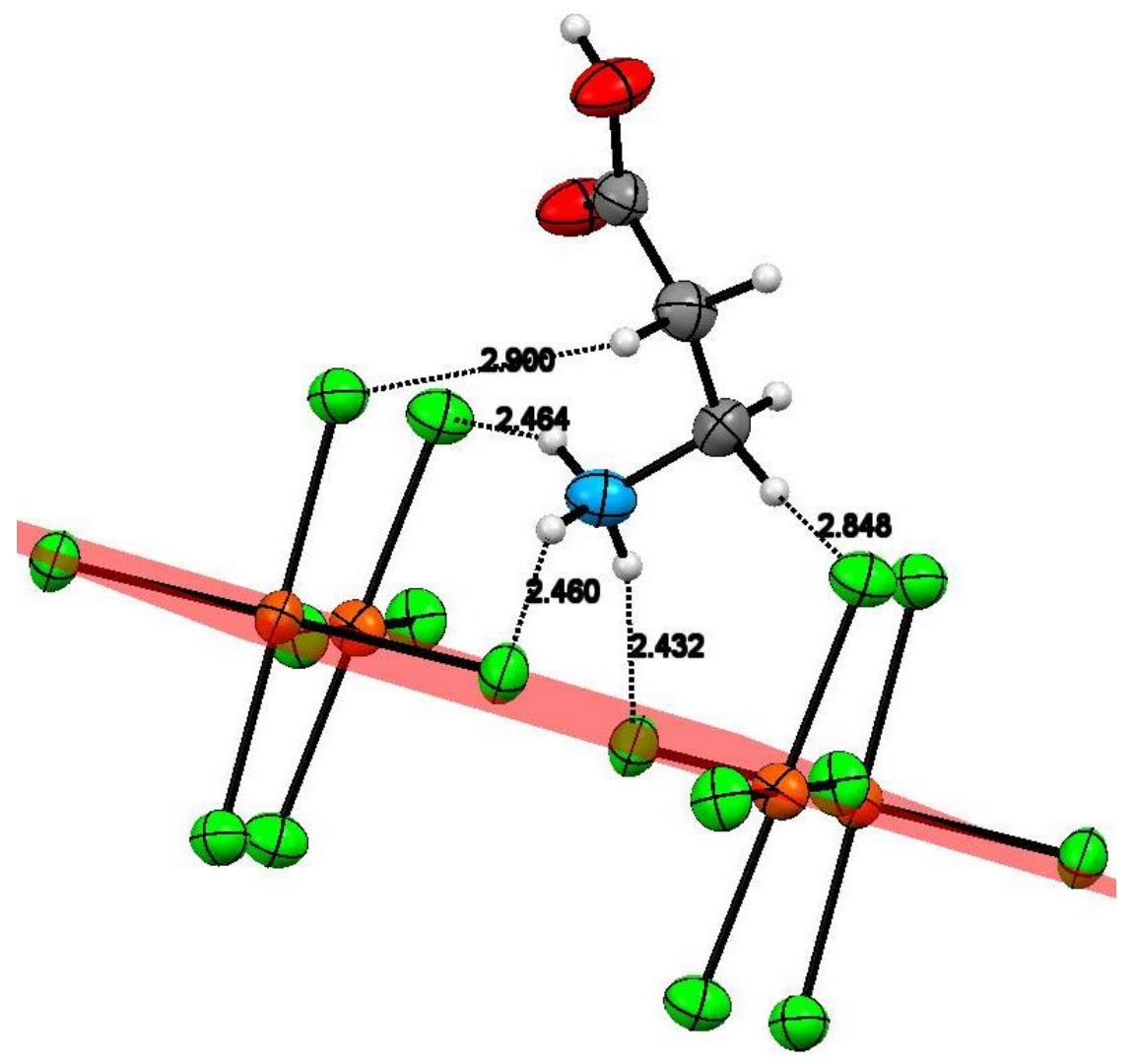

Figure 4: View showing the cohesion between the organic and inorganic chains by $\mathrm{N}-\mathrm{H} \ldots \mathrm{Cl}$ and $\mathrm{C}-\mathrm{H} . . . . \mathrm{Cl}$ hydrogen bonds (dashed lines).

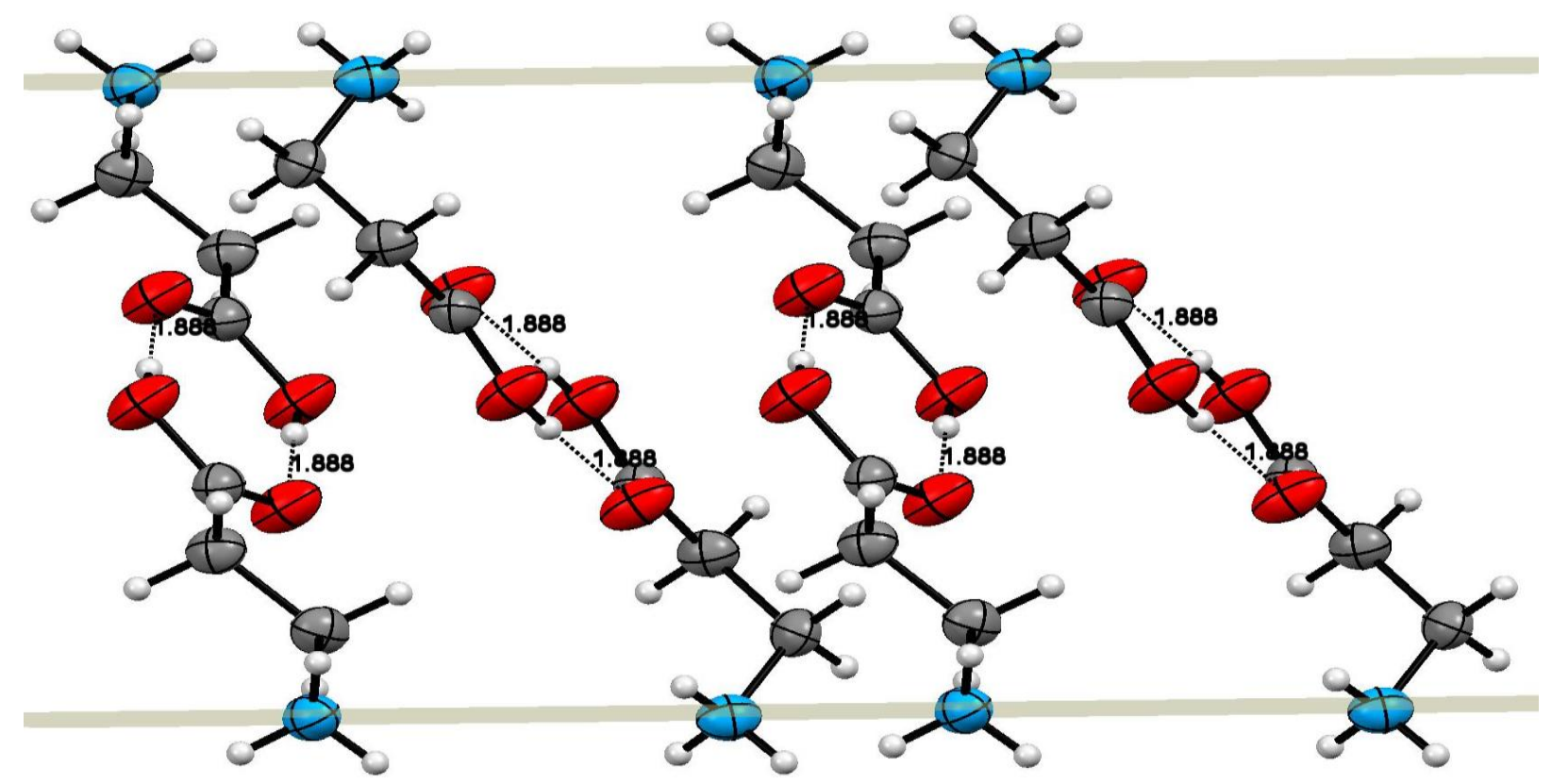

Figure 5: View showing dimer connection between the organic chains by $\mathrm{OH}$...O hydrogen bonds (dashed lines) 


\section{2-2 Micro-Raman spectroscopy analysis}

Figure 6 shows the Raman spectrum of the crystal $\left[\mathrm{NH}_{3}-\left(\mathrm{CH}_{2}\right)_{2}-\mathrm{COOH}\right]_{2} \mathrm{CuCl}_{4}$. From the analysis of this figure, one can observe peaks at low wavenumbers below $400 \mathrm{~cm}^{-1}$. These peaks refer to the inorganic component. At high wavenumbers above $400 \mathrm{~cm}^{-1}$, only the fluorescent shape ascribes to the organic part is observed. This fluorescence infers that the structural characterization of the bulk crystal is not efficient.

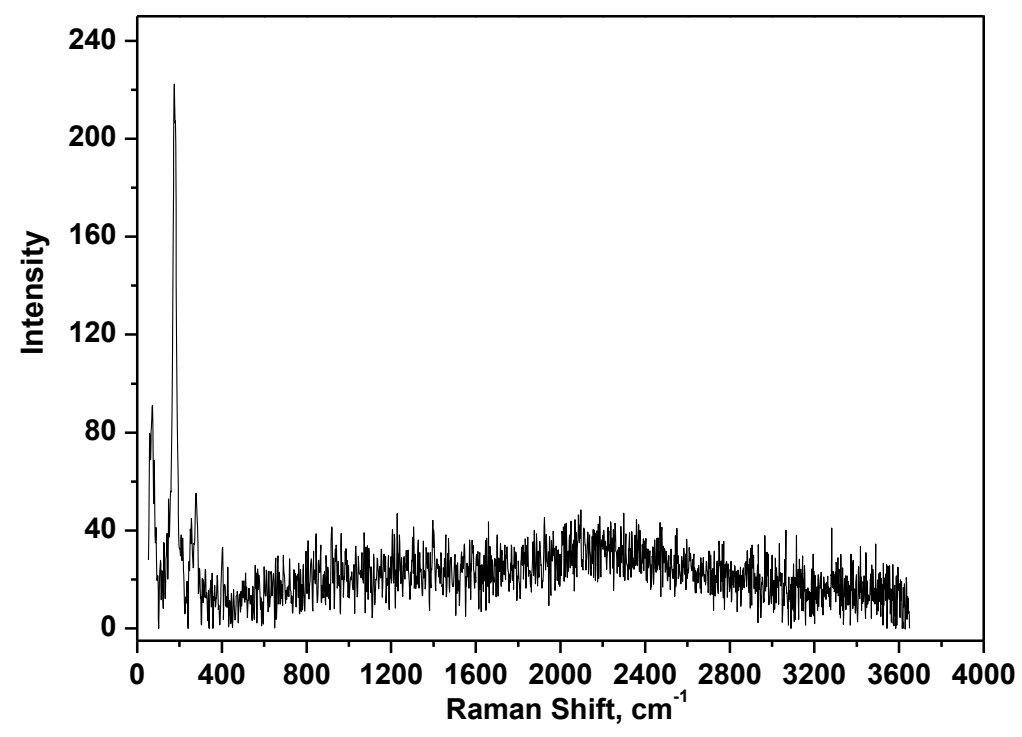

Figure 6. Raman spectrum of $\left[\mathrm{NH}_{3}-\left(\mathrm{CH}_{2}\right)_{2}-\mathrm{COOH}\right]_{2} \mathrm{CuCl}_{4}$ with red Laser $786 \mathrm{~nm}$ at $\mathrm{P}=1 \mathrm{~mW}$

In order to get more insights to the structure, we have used the green Laser at $532 \mathrm{~nm}$. This energetic radiation could contribute to overcome the fluorescent behavior (fluorescence) observed at high frequencies. As a matter of fact, by using this green laser, we have successfully obtained structural information of both the inorganic and the inorganic moieties. Figure 7 gives Raman spectra carried out for different powers of the laser radiation ranging from 0 to $25 \mathrm{~mW}$. It is observed that the peak intensity depends strongly on the working power. In other words, the intensity of each peak varies as a function of the applied power. The more resolved spectrum for the studied crystal is observed at a fixed power $\mathrm{P}=6.25 \mathrm{~mW}$. Each Raman spectrum is divided in two parts: the low frequency range 50$400 \mathrm{~cm}^{-1}$ and the high frequency $400-4250 \mathrm{~cm}^{-1}$. In fact, the first range is ascribed to the inorganic component, while the second last range contains the vibration modes of the organic part. In order to shed more light on the structure one has to assign the observed vibration modes in each frequency range. To achieve this goal, we have considered the spectra carried out at $\mathrm{P}=6.25 \mathrm{~mW}$. 


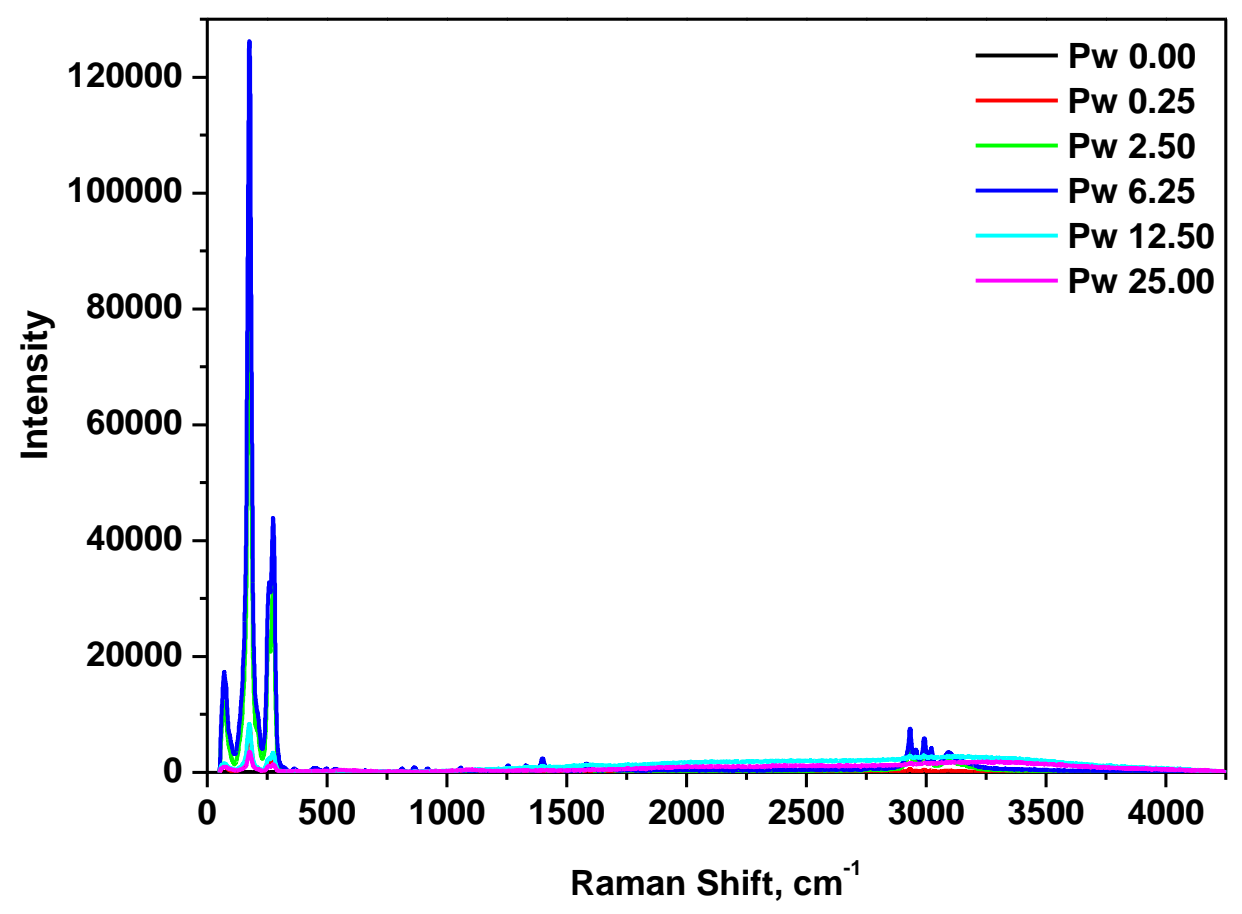

Figure 7. Raman spectrum of $\left[\mathrm{NH}_{3}-\left(\mathrm{CH}_{2}\right)_{3}-\mathrm{COOH}\right]_{2} \mathrm{CuCl}_{4}$ with green Laser $532 \mathrm{~nm}$ for different power $\mathrm{Pw}=0,0.25,2.5,6.25,12.50,25.00 \mathrm{~mW}$

The inorganic $\left[\mathrm{CuCl}_{4}\right]^{2-}$ ion is considered under $\mathrm{C}_{2 \mathrm{~h}}$ symmetry rather than $\mathrm{D}_{2 \mathrm{~h}}$ symmetry, which encompasses the most molecular ions of formula $\left[\mathrm{MX}_{4}\right]^{2-}$. For instance, from the crystal structure, the ion presents a close $\mathrm{C}_{2 \mathrm{~h}}$ symmetry due to (Jahn-Teller effect) with a low local symmetry $\left(\mathrm{C}_{\mathrm{i}}\right)$. The $\mathrm{D}_{2 \mathrm{~h}}$ group contains a subgroup $\mathrm{C}_{2 \mathrm{~h}}$ and the Table 2 describes the correlation between these symmetries [30]. The $\left[\mathrm{CuCl}_{4}\right]^{2-}$ ion presents 18 characteristic internal normal modes shared between the irreducible representations of $C_{2 h}\left(5 A_{g}+4 B_{g}+4 A_{u}+5 B_{u}\right)$ with nine Raman active modes $\left(5 A_{g}+\right.$ $4 \mathrm{~B}_{\mathrm{g}}$. 
Table 2. Correlation between the symmetries of free ion $\mathrm{MX}_{4}\left(\mathrm{D}_{2 \mathrm{~h}}\right)$ and of $\left[\mathrm{NH}_{3}-\left(\mathrm{CH}_{2}\right)_{2^{-}}\right.$ $\mathrm{COOH}]_{2} \mathrm{CuCl}_{4}(\mathrm{P} 21 / \mathrm{c})$ with the symmetry $\mathrm{C}_{2} \mathrm{~h}$.

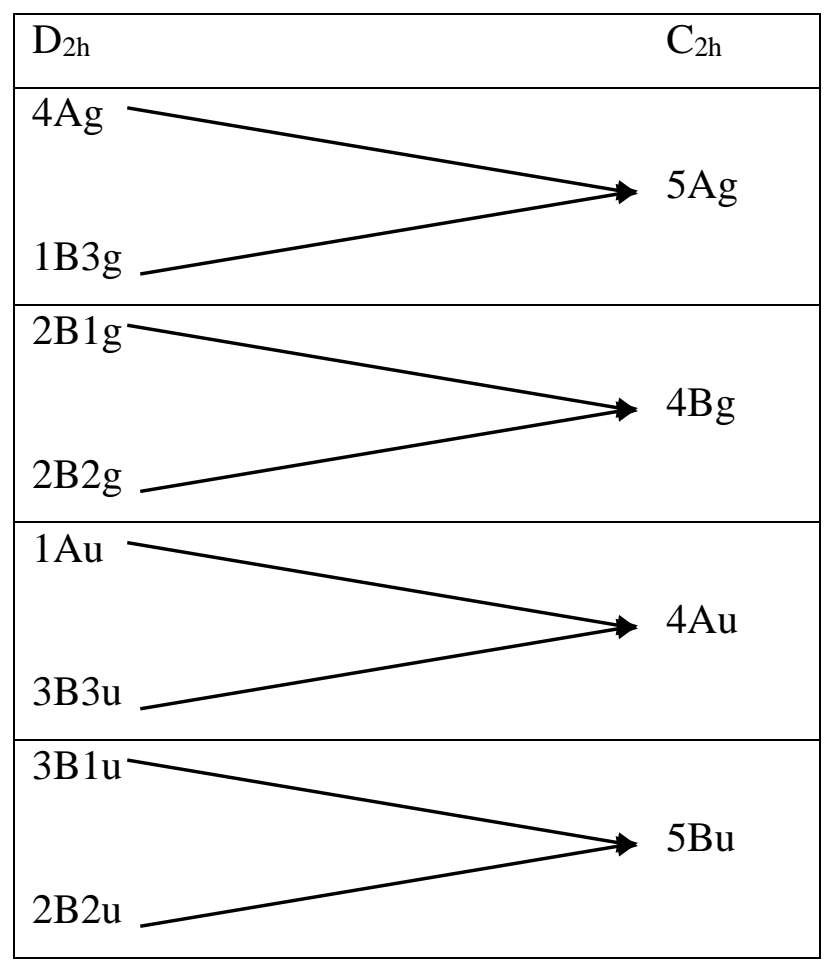

For the frequency region 50-400 $\mathrm{cm}^{-1}$ (Fig.8), all the observed bands are related to the internal modes of the inorganic components $\left(\left[\mathrm{CuCl}_{4}\right]^{2-}\right)$ and the external modes of the organic cation $\left(\left[\mathrm{NH}_{3}-\left(\mathrm{CH}_{2}\right)_{2-}\right.\right.$ $\mathrm{COOH}]^{+}$). The attributions of these modes are realized according to the literature data [31-34]. The bands located at 73 and $175 \mathrm{~cm}^{-1}$ are assigned to the symmetric $\mathrm{v}_{2}$ and asymmetric $\mathrm{v}_{4}$ bending modes of the $\mathrm{Cl}-\mathrm{Cu}-\mathrm{Cl}$ in square plan symmetry. While the stretching modes $\mathrm{v}_{1}$ symmetric and $\mathrm{v}_{3}$ asymmetric of the $\mathrm{Cu}-\mathrm{Cl}$ bonds are observed at 256 and $276 \mathrm{~cm}^{-1}$. 


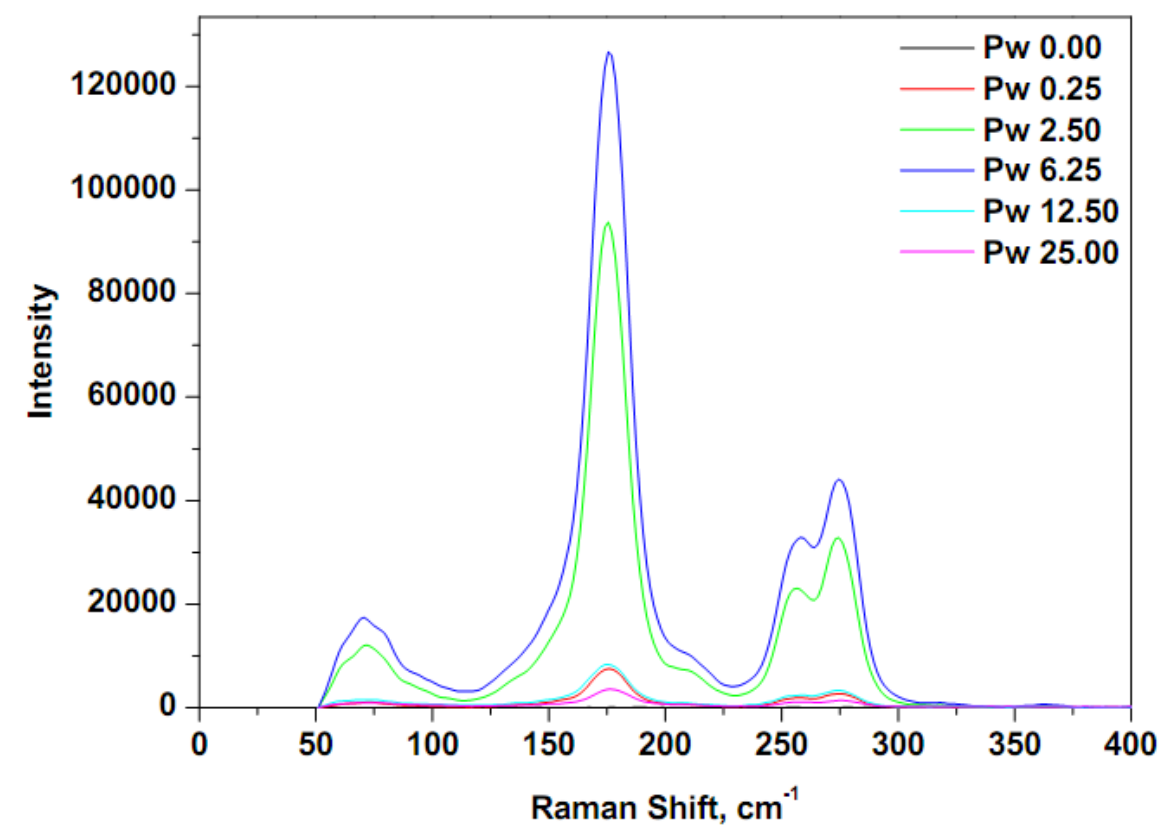

Figure 8. Raman spectrum of $[\mathrm{NH} 3-(\mathrm{CH} 2) 2-\mathrm{COOH}] 2 \mathrm{CuCl} 4$ in the range $50-400 \mathrm{~cm}-1$, with red Laser $786 \mathrm{~nm}$ at $\mathrm{P}=1 \mathrm{~mW}$

Above $400 \mathrm{~cm}^{-1}$ (Fig.9), the Raman active modes are associated to stretching modes of the organic cation, the bands located at 495, 573, 660 and $811 \mathrm{~cm}^{-1}$ are characteristic respectively to twisting mode of $\mathrm{NH}_{3}$ groups, $\mathrm{C}-\mathrm{CO}$ in plane deformation vibration, out and in plane deformation vibrations of C-O. The C-H bond exhibits a rocking vibration at $862 \mathrm{~cm}^{-1}$, the stretching vibrations $\mathrm{v}(\mathrm{C}-\mathrm{C})$ and $\mathrm{v}(\mathrm{O}-\mathrm{H})$ are located at 918 and $949 \mathrm{~cm}^{-1}$, respectively. The $\mathrm{C}-\mathrm{C}$ skeletal vibrations and the $\mathrm{C}-\mathrm{N}$ stretching vibrations are observed at 1056 and $1078 \mathrm{~cm}^{-1}$, while the bands located at 1254, 1330 and $1396 \mathrm{~cm}^{-1}$ are assigned to rocking vibration of $\mathrm{NH}_{3}$ groups, $\mathrm{O}-\mathrm{H}$ deformation vibration and wagging vibration of $\left(\mathrm{CH}_{2}\right)$. The band observed at $1465 \mathrm{~cm}^{-1}$ is assigned to deformation vibration of $\mathrm{CH}_{2}$.

The asymmetric and symmetric deformation vibrations of $\mathrm{NH}_{3}{ }^{+}$are located respectively at 1579 and $1602 \mathrm{~cm}^{-1}$, and the stretching bands of $\mathrm{C}=\mathrm{O}$ is located at $1678 \mathrm{~cm}^{-1}$. The symmetric and asymmetric stretching vibrations of O-H bond are showed at 2931 and $2990 \mathrm{~cm}^{-1}$. The symmetric and asymmetric stretching of $\mathrm{C}-\mathrm{H}$ bond are located at 2955 and $3019 \mathrm{~cm}^{-1}$, respectively, and the stretching vibration of $\mathrm{NH}_{3}{ }^{+}$is located at $3097 \mathrm{~cm}^{-1}$. 


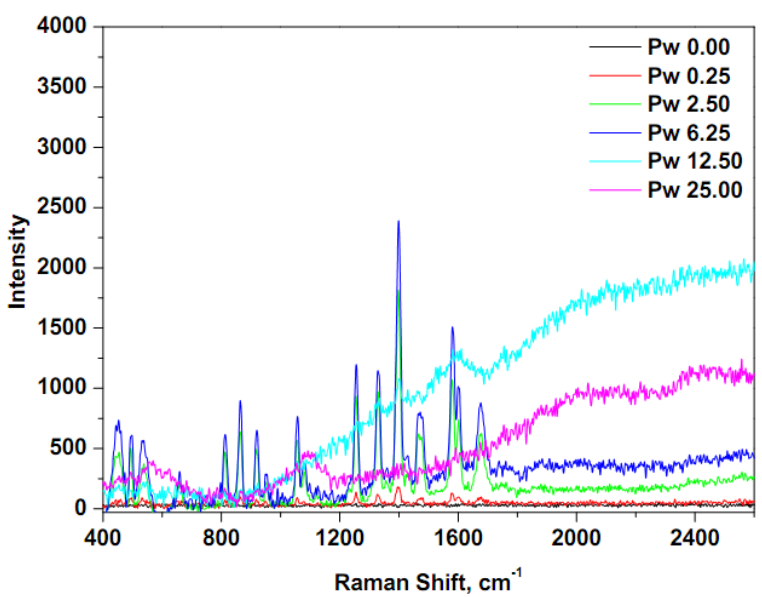

(a)

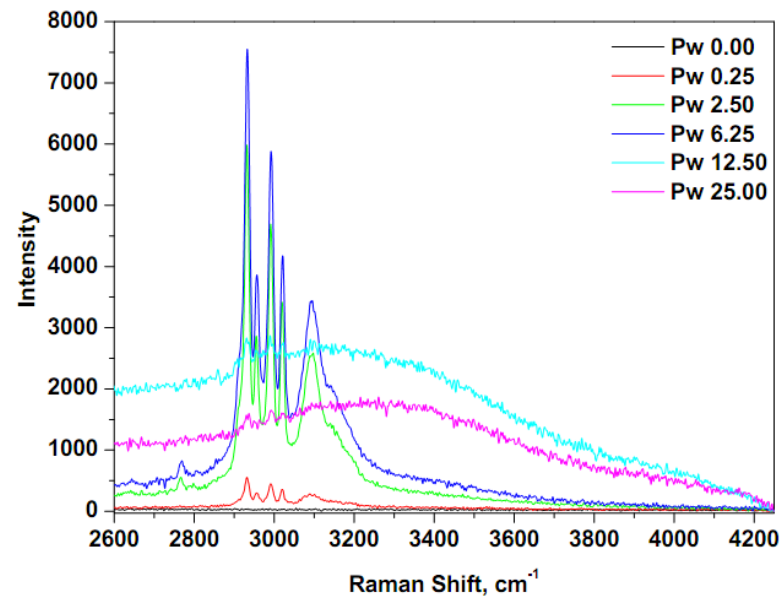

(b)

Figure 9. Raman spectrum of $\left[\mathrm{NH}_{3}-\left(\mathrm{CH}_{2}\right)_{2}-\mathrm{COOH}\right]_{2} \mathrm{CuCl}_{4}$ in the range a) $400-2600 \mathrm{~cm}^{-1}$, b) $2600-4250 \mathrm{~cm}^{-1}$, with red Laser $786 \mathrm{~nm}$ at $\mathrm{P}=1 \mathrm{~mW}$

From the shape of the Raman spectra, one can notice that the intensity of the inorganic and organic peaks increases up to the power $\mathrm{P}=6.25 \mathrm{~mW}$ and thereafter it decreases (Fig. 10). This latter Figure demonstrates that above this threshold power, the intensity of the peaks relatives to the mineral component decreases rapidly. On the other hand, for the organic entities, the intensity of the Raman peaks, above $\mathrm{P}=6.25 \mathrm{~mW}$, decreases suddenly with the appearance of the fluorescent shape at high frequency range (Figure 9 (a), and 9 (b)). The occurrence of this fluorescence could be due to the creation of hot points inside the crystal material. Such hot point induces the decomposition of the organic moieties as shown in Figure 11. The latter illustrates the burning of the material submitted to higher laser radiation power. 


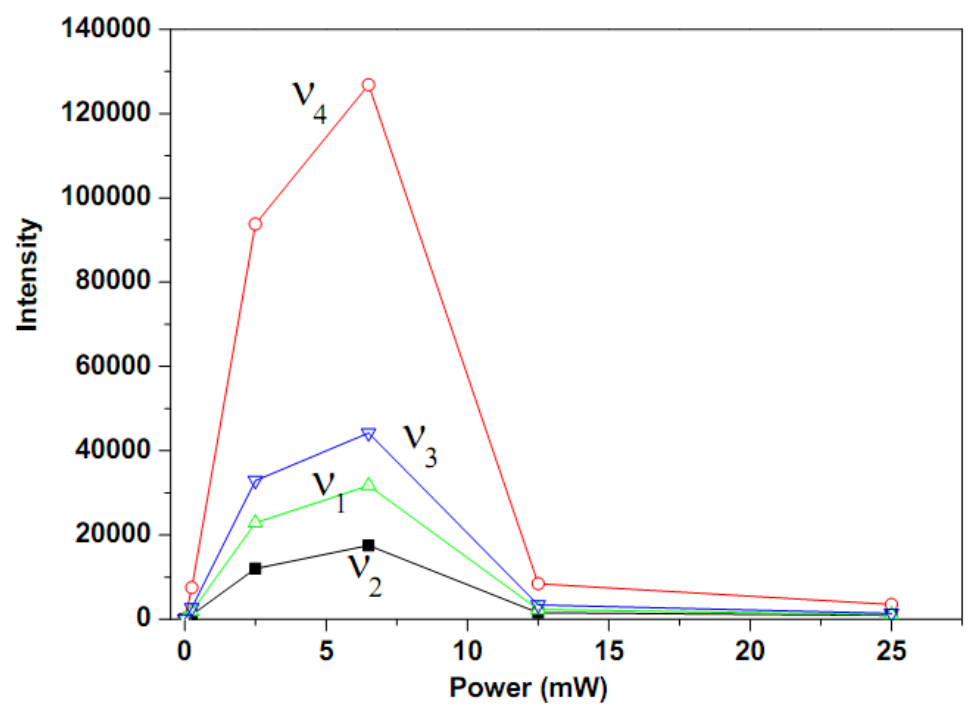

Figure 10. Evolution of intensity of $v_{1}, v_{2}, v_{3}$ and $v_{4}$ modes as function of the laser power

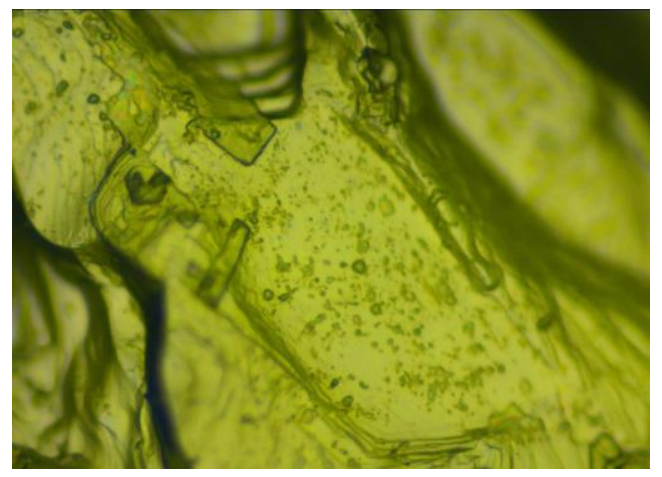

a)

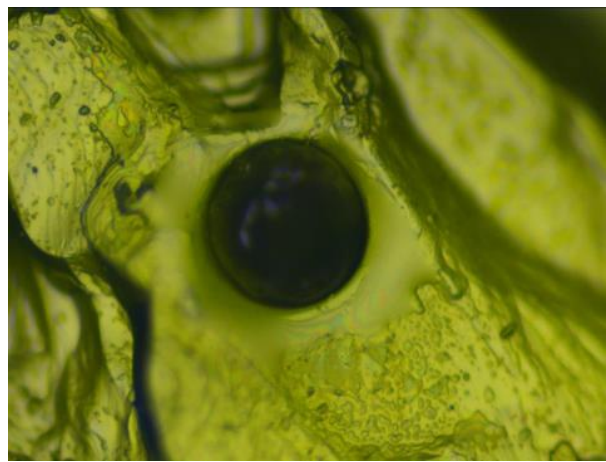

b)

Figure 11. Raman associated sample image, a) for power under $6.25 \mathrm{~mW}$, b) for power upper to $6.25 \mathrm{~mW}$.

\section{Conclusion}

In summary, we have synthetized single crystal of new copper(I1) halide layer perovskite salts $\left[\mathrm{NH}_{3}-\right.$ $\left.\left(\mathrm{CH}_{2}\right)_{2}-\mathrm{COOH}\right]_{2} \mathrm{CuCl}_{4}$ by slow diffusion at room temperature. The formula unit is formed by $\left[\mathrm{CuCl}_{2}\right]^{-1}$ and protonated ${ }^{+} \mathrm{NH}_{3}(\mathrm{CH} 2)_{2} \mathrm{CO}_{2} \mathrm{H}$ entities. The antiferrodistortive Jahn-Teller distortion effect produced by $\mathrm{Cu}^{2+}$ Metal cation introduces distortion of the $\mathrm{CuCl}_{6}$ octahedron. The crystal structure is stabilized via various kinds of hydrogen bonds interactions. The compound has ionic structure with packing of the $\left[\mathrm{CuCl}_{4}\right]^{2-}$ and ${ }^{+} \mathrm{NH}_{3}(\mathrm{CH} 2)_{2} \mathrm{CO}_{2} \mathrm{H}$ ions in the form of bilayered 
perovskite system. The vibrational properties of this structure were studied by Micro-Raman spectroscopy at different power. The more resolved spectrum is observed at fixed power $\mathrm{P}=6.25 \mathrm{~mW}$. The attribution of the vibrational bands was carried by comparison with the vibration modes frequencies of homologous compound. Above a certain threshold there is creation of hot point inside the crystal material and this induces the decomposition or the burning of the compound. From the present study it is worth to notice that the structure of the investigated hybrid materials is very promising for many applications.

\section{References}

[1] D.B. Mitzi, Synthesis, structure, and properties of organic-inorganic perovskites and related materials, Progress in inorganic chemistry (1999) 1-121.

[2] K. Matsuishi, T. Ishihara, S. Onari, Y. Chang, C. Park, Optical properties and structural phase transitions of lead-halide based inorganic-organic 3D and 2D perovskite semiconductors under high pressure, physica status solidi (b) 241(14) (2004) 3328-3333.

[3] X. Liu, W. Zhao, H. Cui, Y.a. Xie, Y. Wang, T. Xu, F. Huang, Organic-inorganic halide perovskite based solar cells-revolutionary progress in photovoltaics, Inorganic Chemistry Frontiers 2(4) (2015) 315-335.

[4] M.A. Green, A. Ho-Baillie, H.J. Snaith, The emergence of perovskite solar cells, Nature photonics 8(7) (2014) 506.

[5] M.A. Green, T. Bein, Photovoltaics: Perovskite cells charge forward, Nature materials 14(6) (2015) 559.

[6] J. Zhang, P. Barboux, T. Pauporté, Electrochemical design of nanostructured ZnO charge carrier layers for efficient solid-state perovskite-sensitized solar cells, Advanced Energy Materials 4(18) (2014) 1400932.

[7] M. Shahzad, F. Sultan, M. Ali, W. Khan, M. Irfan, Slow invariant manifold assessments in multi-route reaction mechanism, Journal of Molecular Liquids 284 (2019) 265-270.

[8] M. Shahzad, F. Sultan, S.I.A. Shah, M. Ali, H.A. Khan, W.A. Khan, Physical assessments on chemically reacting species and reduction schemes for the approximation of invariant manifolds, Journal of Molecular Liquids 285 (2019) 237-243.

[9] F. Sultan, M. Shahzad, M. Ali, W.A. Khan, The reaction routes comparison with respect to slow invariant manifold and equilibrium points, AIP Advances 9(1) (2019) 015212.

[10] M. Shahzad, F. Sultan, I. Haq, M. Ali, W. Khan, C-matrix and invariants in chemical kinetics: A mathematical concept, Pramana 92(4) (2019) 64.

[11] A.M. Leguy, Y. Hu, M. Campoy-Quiles, M.I. Alonso, O.J. Weber, P. Azarhoosh, M. Van Schilfgaarde, M.T. Weller, T. Bein, J. Nelson, Reversible hydration of $\mathrm{CH} 3 \mathrm{NH} 3 \mathrm{Pbl} 3$ in films, single crystals, and solar cells, Chemistry of Materials 27(9) (2015) 3397-3407.

[12] Y. Dang, Y. Liu, Y. Sun, D. Yuan, X. Liu, W. Lu, G. Liu, H. Xia, X. Tao, Bulk crystal growth of hybrid perovskite material CH 3 NH 3 Pbl 3, CrystEngComm 17(3) (2015) 665-670.

[13] J.H. Heo, S.H. Im, J.H. Noh, T.N. Mandal, C.-S. Lim, J.A. Chang, Y.H. Lee, H.-j. Kim, A. Sarkar, M.K. Nazeeruddin, Efficient inorganic-organic hybrid heterojunction solar cells containing perovskite compound and polymeric hole conductors, Nature photonics 7(6) (2013) 486.

[14] R. Liu, Hybrid organic/inorganic nanocomposites for photovoltaic cells, Materials 7(4) (2014) 2747-2771.

[15] Y. Zhao, A.M. Nardes, K. Zhu, Solid-state mesostructured perovskite CH3NH3Pbl3 solar cells: charge transport, recombination, and diffusion length, The journal of physical chemistry letters 5(3) (2014) 490-494.

[16] G. Peng, X. Xu, G. Xu, Hybrid organic-inorganic perovskites open a new era for low-cost, high efficiency solar cells, Journal of Nanomaterials 2015 (2015) 2. 
[17] G.V. Prakash, Naturally self-assembled nanosystems and their templated structures for photonic applications, Journal of Nanoparticles 2013 (2013).

[18] G. Breneman, R. Willett, Diethylenetriammonium tetrachloromanganate (II) chloride, Acta Crystallographica Section B: Structural Crystallography and Crystal Chemistry 37(6) (1981) 1292-1294.

[19] N. Mercier, $(\mathrm{HO} 2 \mathrm{C}(\mathrm{CH} 2)(3) \mathrm{NH} 3)(2)(\mathrm{CH} 3 \mathrm{NH} 3) \mathrm{Pb} 217$ : a predicted noncentrosymmetrical structure built up from carboxylic acid supramolecular synthons and bilayer perovskite sheets, CrystEngComm 7 (2005) 429432.

[20] M.B. AlShammari, A. Kaiba, P. Guionneau, M.H. Geesi, T. Aljohani, Y. Riadi, Phase transitions, optical and electronic properties of the layered perovskite hybrid $[\mathrm{NH} 3(\mathrm{CH} 2) 2 \mathrm{COOH}] 2 \mathrm{CdCl} 4$ of $\mathrm{Y}$-aminobutyric acid (GABA), Chemical Physics Letters 702 (2018) 8-15.

[21] B. Saparov, D.B. Mitzi, Organic-inorganic perovskites: structural versatility for functional materials design, Chemical reviews 116(7) (2016) 4558-4596.

[22] S.F. Hoefler, G. Trimmel, T. Rath, Progress on lead-free metal halide perovskites for photovoltaic applications: a review, Monatshefte für Chemie-Chemical Monthly 148(5) (2017) 795-826.

[23] C.B. Mohamed, K. Karoui, A. Bulou, A.B. Rhaiem, Raman studies of phase transitions in ferroelectric [C2H5NH3] 2ZnCl4, Physica E: Low-dimensional Systems and Nanostructures 87 (2017) 141-149.

[24] A. Kessentini, M. Belhouchet, J. Suñol, Y. Abid, T. Mhiri, Synthesis, structural, photoluminescence, vibrational and DFT investigation of the bis (4-aminopyridinium) tetrachloridocuprate (II) monohydrate, Journal of Luminescence 149 (2014) 341-347.

[25] A. Altomare, M.C. Burla, M. Camalli, G.L. Cascarano, C. Giacovazzo, A. Guagliardi, A.G. Moliterni, G. Polidori, R. Spagna, SIR97: a new tool for crystal structure determination and refinement, Journal of Applied Crystallography 32(1) (1999) 115-119.

[26] G. Sheldrich, SHELX-97, release 97-2, University of Goettingen, Germany (1998).

[27] L.J. Farrugia, WinGX suite for small-molecule single-crystal crystallography, Journal of Applied Crystallography 32(4) (1999) 837-838.

[28] K. Brandenburg, DIAMOND 3.1 a., version 1.1 a, Crystal Impact GbR, Bonn, Germany 2005 (1997).

[29] C.F. Macrae, I.J. Bruno, J.A. Chisholm, P.R. Edgington, P. McCabe, E. Pidcock, L. Rodriguez-Monge, R. Taylor, J.v.d. Streek, P.A. Wood, Mercury CSD 2.0-new features for the visualization and investigation of crystal structures, Journal of Applied Crystallography 41(2) (2008) 466-470.

[30] A. Oueslati, A. Bulou, F. Calvayrac, K. Adil, M. Gargouri, F. Hlel, Infrared, polarized Raman and ab initio calculations of the vibrational spectra of [N (C3H7) 4] 2Cu2Cl6 crystals, Vibrational Spectroscopy 64 (2013) 10-20.

[31] K. Karoui, M.B. Bechir, A. Bulou, K. Guidara, A.B. Rhaiem, [N (CH3) 3H] 2CuCl4: Ab initio calculations and characterization of phase transitions by Raman spectroscopy, Journal of Molecular Structure 1114 (2016) 161-170.

[32] E. Smith, G. Dent, Modern Raman spectroscopy: a practical approach, Wiley2019.

[33] A. Caretta, R. Miranti, R.W. Havenith, E. Rampi, M.C. Donker, G.R. Blake, M. Montagnese, A.O. Polyakov, R. Broer, T.T. Palstra, Low-frequency Raman study of the ferroelectric phase transition in a layered $\mathrm{CuCl} 4$ based organic-inorganic hybrid, Physical Review B 89(2) (2014) 024301.

[34] J.R. Ferraro, Low-frequency vibrations of inorganic and coordination compounds, Springer Science \& Business Media2012. 